\title{
CRIME COGNITION LIMITS IN MODERN UKRAINIAN CRIMINOLOGY SCIENCE
}

\section{Smetanina N. V.}

\section{INTRODUCTION}

Crime, its essence and nature related to the subject of science of criminology, is an important object of study in the domestic legal system. Studying the phenomenon of crime nowadays plays an important role in the legal life of society, and therefore has a significant place in criminology research. The growth in crime dynamics, the complexity of its structure, and the ineffectiveness of prevention measures may indicate that there is a lack of theoretical development on the concept of crime as an object of preventive influence. The necessity to identify such an object arises from the practice requirements.

By today, in the twenty-first century, it has become apparent that the cognition of the nature of crime is still ongoing and is experiencing a major crisis. Protection against crime and violence remain a priority for people around the world. The question is: what's changing by today? What is a real threat to society now?

The modern science of criminology has faced the complex nature of statelegal construction in an independent state of Ukraine. With the proclamation of state independence of Ukraine, significant social-political, legal, economic and criminological changes took place, the social-psychological climate in the society worsened rapidly due to the sharp changes that took place. The beginning of the 90 -ies of the last century was characterized by a significant "collapse" of law-abiding justice and an increase in the criminal-legal consciousness of the population not only in Ukraine but also in the CIS countries close to it. All this was reflected in the level and structure of crime in Ukraine in the early 1990s.

Research and definition of the crime cognition limits in modern domestic criminology is an unresolved and complex issue, as well as the phenomenon of crime itself. In our society, crime as a phenomenon has created its own shell of life. Cogitations that the criminal acts were committed yesterday, they are committed today and will be committed tomorrow, are no longer in dispute. In order to understand the nature of crime, it is also important to know that it reflects the peculiarities, contradictions and deformities of social being. Crime is an extreme form of the contradictions of social development ${ }^{1}$. In addition, it is a phenomenon that has a high latency, which actually complicates

\footnotetext{
1 Карпец И.И. Преступность как реальность. Вопросы философии. 1989. № 5. С. 87.
} 
the possibility of its cognition and allows investigating only those criminal acts that have entered the orbit of criminal justice. Recently, more and more facts are emerging confirming that crime is directly dependent on social conditions, especially on the difficult economic situation of the population and the negative social-economic climate in society ${ }^{2}$.

Formulation and identification of the problem of the possibility of cognition of crime, the study of its boundaries are due primarily to both the significant development of the science of criminology, and the change in social relations and legal awareness. The current level of criminal science proves that crime as the central concept of criminology cannot be studied only within the framework of the achievements of Soviet science, which are certainly significant and fruitful. The present (current state of societal societies) requires criminologists to have a new vision of crime and the possibilities of its cognition ${ }^{3}$. Indeed, crime is a universal and transnational phenomenon; it is not limited either by the boundaries of the social formation, or even more so, by national or regional borders ${ }^{4}$.

\section{Crime in Ukraine: the major issues}

523,911 criminal offenses were registered in Ukraine in 2017 and 487,133 criminal offenses in $2018^{5}$. In the structure of the whole crime in Ukraine mercenary-minded crimes take nearly $67 \%$ where thefts take the biggest place. This demonstrates the need to intensify the fight against mercenary-minded offenses by law enforcement agencies. The dynamics of crimes against the life and health of the individual is negative and amounts to $5.2 \%$, which generally corresponds to the trends of violent crime over the last five years. The relative share of violent offenses is $8 \%$ of the total number of reported offenses. Violent and mercenary-minded offenses in the structure of crime amount to around $10 \%$.

It should be noted that prior to the start of the Anti-Terrorist Operation in eastern Ukraine, the level of terrorist offenses was negligible (2012-0; $2013-7)$. But since 2014, the level of these criminal offenses has increased hundreds of times. During the period 2014-2017 (for four years), 8,431 criminal offenses were noted, which is an average of 2,108 crimes

\footnotetext{
2 Рагимов И.М. Преступность и наказание : монография. Москва : ОЛМА Медиа Групп, 2012. C. 144-145.

3 Парсонс Т. Система современных обществ. Москва : Аспект Пресс, 1998. С. 158-162.

4 Бабаев М.М., Квашис В.Е. Преступность и политика в общественных формациях переходного периода. Право и политика. 2001. № 2. С. 124-125.

5 Statistics on Crime in Ukraine. URL: https://www.gp.gov.ua/en/statinfo.html (accessed 08.09.2019).
} 
per year. In 2018, 1,181 terrorist offenses were noted. According to official statistics before 2014, the problem of terrorism did not threaten Ukrainian society at all. Thus, single displayings of terrorism today have grown into a mass socially dangerous social phenomenon. Thus, in the Global Terrorism Index, which is developed to determine the level of vulnerability of states to terrorist threats, with the onset of armed aggression of the Russian Federation against Ukraine, Ukraine has moved from 51st (2013) to 21 st place (2018) among 163 countries.

The evolutionary development of crime, its capacity for selfdetermination, self-reproduction, and the change of social relations, compels the legislator to introduce new offenses that were not previously known by criminal law, to timely and effectively counter crime displayings and protect social institutions. For example, there were articles of the 2001 Criminal Code that, for example, were not known to the criminal legislation of the Soviet era: a terrorist act; use of a minor child for begging; illicit circulation of CDs for laser reading systems, matrices, equipment and raw materials for their production; gambling; manipulation at the stock market; illegal use of insider information; adulteration of drugs or circulation of adulterated medicines and many others. This forces the displayings of crime to be redefined and to take a fresh look at its nature.

Crime is in actual fact a universal phenomenon. The crime rate has reached alarming dimensions around the world, and effective control of it has become one of the global problems of today, requiring a comprehensive approach $^{6}$. Though scientists say that in developed countries, crime rates are declining, meanwhile in developing countries it is steadily rising? Ukraine belongs to a group of developing countries today. Scientific literature indicates that societies that profess universal values and respect their citizens, and concern for their well-being are low-crime societies. Fear of crime may affect public opinion in favor of a return to harsher sanctions, while human rights will be violated ${ }^{8}$. Moreover, current research has shown that fear of crime generates crime itself, because the victim's fear causes the offender a sense of confidence and the victim a sense of helplessness. The fear of crime and awareness of the potential for being a victim of criminal act in modern society has grown significantly (compared to the years 80-90)

\footnotetext{
6 Шабалин В.А. Политика и преступность. Государство и право. 1994. № 4. С. 43.

7 Травис Дж. Международные стратегии предупреждения преступности в обществах переходного периода: проблемы и перспективы. Право и политика. 2001. № 2. С. 126.

8 Травис Дж. Международные стратегии предупреждения преступности в обществах переходного периода: проблемы и перспективы. Право и политика. 2001. № 2. С. 127, 129.
} 
and is more relevant to people than, for example, the fear of old age or illness ${ }^{9}$. Against this background, there is a change in social consciousness, an adaptation to life in a society in which there is an objective threat to human $\operatorname{life}^{10}$. So, H.A. Avanesov emphasizes that crime proves to be most dangerous when every person feels its active influence on themselves and on their close people, feels a real threat, which prevents them from regular living and working ${ }^{11}$.

Modern society is built on rationality, but criminal act often goes beyond that ${ }^{12}$. The famous criminologist N. Kristi states that a new situation has emerged in society, which is characterized by the inexhaustibility of the source of the actions that can be defined as criminal acts ${ }^{13}$. However, the study of crime requires a clear definition of the boundaries of the existence and activity of this phenomenon.

Criminologists as specialists in the crime problem must also solve the following question: why are psychologically normal, convicted persons who can realize the actual nature and public danger of their actions (inaction), and can choose in a particular situation another, non-criminal, behavioral option, still committing criminal acts? ${ }^{14}$.

In this aspect, it is appropriate to study such a category as the "borders" of crime. It is the category that makes it possible to identify crime as a phenomenon and limit it with quantitative and qualitative indicators. Borders also give an idea of the "coverage" of crime by criminal statistics, that is, how representative does it reflect criminal reality.

The problem of determining the boundaries of crime cognition include the question of the place and functions of crime in modern society, understanding of crime as a criminal practice of people, the criminal conditionality of criminal act, the phenomenon of latent crime, the possibility of combating the phenomenon of crime. In criminological study of crime, it is necessary to identify its general prevalence and social danger in specific

\footnotetext{
9 Васильченко Г.С. Страх перед преступностью в современном обществе. Правова держава. 2001. № 3. С. 116-119.

10 Ройбанд К.Х. От истерии вокруг преступности к нормальному состоянию? Социологические исследования. 2001. № 11. С. 77-83.

11 Аванесов Г.А. Преступность и социальные сословия. Криминологические рассуждения : монография. Москва : ЮНИТИ-ДАНА, 2010. С. 14.

12 Кристи Н. Контроль над преступностью как индустрия. Вперед, к ГУЛАГу западного образца. Санкт-Петербург : Алетейя, 2012. С. 163.

13 Кристи Н. Контроль над преступностью как индустрия. Вперед, к ГУЛАГу западного образца. Санкт-Петербург : Алетейя, 2012. С. 15-16.

14 Личность организованного преступника: криминологическое исследование : монография / под ред. А.И. Долговой. Москва : Норма: ИНФРА-М, 2013. С. 29.
} 
conditions of the place and time in order to assess its state and trends, determine the directions of combating crime; as well as the social nature of the crime; inherent, "internal" nature of crime ${ }^{15}$.

When studying crime, it is important to find not only the most common characteristics, not only the common in crime of different regions, representatives of different social groups, different types of crime, but also differences, features, in order to provide practical activity differentially, taking into account these features. The analysis of crime should have a promising character, in other words, not to fix its past conditions, but also to give grounds for the forecast ${ }^{16}$.

In the Ukrainian criminal science, the issue under study had to some extent become the subject of scientific research and debate for such scientists as V.V. Holin, I.M. Danshyn, V.M. Dromin, A.P. Zakaliuk, O.M. Kostenko, V.F. Obolentsev, I.P. Rushchenko, V.O. Tuliakov, V.I. Shakun and others. In deciding the boundaries of crime cognition the scientific works of Russian criminologists H.A. Avanesov, Yu.M. Antonian, Ya.I. Hilinskyi, A.I. Dolhova, S.M. Inshakova, I.I. Karpets, D.O. Li, V.V. Lunieiev, I.M. Rahimov, O.M. Smyrnov, D.A. Shestakov and others should also be taken into account.

Exploring the boundaries of the crime cognition in modern science, it should be noted that along with the study of the phenomenon of crime and its negative consequences, there are opinions that crime is a normal function of society; a product of civilization, part of modern culture; indicator of social pathology ${ }^{17}$. For example, F. Tanenbaum wrote in 1943 that "crime is eternal just like society... The more complex it becomes, the more difficult it is for the individual and the more frequent its breakdown happens..." According to J. Floryty, crime, like a sin, is a normal phenomenon in society; abnormal are sanctions and laws invented by people. A similar view was expressed in 1890 by E. Diurkheim ${ }^{18}$. The famous philosopher V.A. Bachynin emphasizes that criminal acts allow certain categories of individuals to realize their transgressive inclinations. Criminal acts test the strength and reliability of regulatory-valuable structures of civilization, forcing it to constantly engage in strengthening its foundations, to maintain in a state of readiness the means of restraining and blocking the destructive pressure of the criminal

\footnotetext{
15 Долгова А.И. Криминология : учебник. Москва : НОРМА, 2002. С. 62-63.

16 Криминология : учебник для вузов / под общ. ред. А.И. Долговой. Москва : НОРМА,, 2000. C. $112-113$.

17 Бачинин В.А. Философия права : конспект лекций. Харьков : Консум, 2002. С. 19-22.

18 Фокс В. Введение в криминологию.Москва : Прогресс, 1985. С. 19-20.
} 
environment. The offender chooses false and tragic ways to resolve the existing contradictions of the social-historical process ${ }^{19}$. However, we cannot accept this position, because interpreting crime as a normal function of society negates criminological opinion, as well as thoughts about the eternal and innate (genetic) nature of crime. It is more correct to speak about a person's genetic necessity for destruction without identifying the commission of a specific criminal act and the phenomenon of crime in general. The thoughts of famous scientists on this issue should also be cited.

The main representative of neo-Freudism, the German philosopher, psychologist and sociologist Erikh Fromm (1900-1980) critically reinterpreted the Freudian point of view on the nature of unconscious drives and the role of social factors in the formation of personality [66, p. 81]. In the famous work "The Anatomy of Human Destructiveness" E. Fromm states: "I distinguish a specific human passion for absolute dominance over another living creature (criminal aggression) into a special group and call it "destructiveness" and "cruelty", which do not have in my opinion, the "phylogenetic program," does not serve biological adaptation and has no purpose ${ }^{20}$. By considering the nature of human destructiveness, the scientist distinguished between biologically adaptive (non-criminal) and biologically non-adaptive (criminal) aggression. The first is a reaction to the threat to the vital interests of the individual; it is inherent in phylogenesis, characteristic of both animals and humans; it is explosive in nature and occurs suddenly as a reaction to a threat from the outside, and its consequences are to eliminate the threat itself or its cause. In other words, adaptive aggression is an instinct. The second (destructiveness and cruelty) is not at all a defense against attack and is not inherent in phylogenesis, but is a characteristic only of man; it causes biological damage and leads to social destruction. The basis of biological criminal aggression is not an instinct, but a certain human potential, rooted in the conditions of human existence ${ }^{21}$. Recall that such a view exists, and it can be agreed or denied. For example, E. Fromm notes that man is different from animal in that he is a killer. The lack of instinct in the human "thou shalt not kill" poses a serious threat to the world. Human destructiveness has a genetic (inherent) origin ${ }^{22}$. In his

\footnotetext{
19 Бачинин В.А. Философия права : конспект лекций. Харьков : Консум, 2002. С. 331-333.

20 Фромм Э. Анатомия человеческой деструктивности. Москва: ООО «Издательство АСТ-ЛТД», 1998. С. 18, 22.

21 Фромм Э. Анатомия человеческой деструктивности. Москва : ООО «Издательство АСТ-ЛТД», 1998. С. 33-34, 52, 333.

22 Фромм Э. Анатомия человеческой деструктивности. Москва : ООО «Издательство АСТ-ЛТД», 1998. С. 34, 167, 175.
} 
work "Man for himself", the scientist poses a rather problematic question: man - good or evil? He says that man is not only destructive towards others, but also destroys his own life ${ }^{23}$.

And when he teaches the story of the criminal act, reflecting on its causes, not the author of minor detectives, but a brilliant writer and thinker, his reflections inevitably acquire a higher, metaphysical meaning. This is exactly what the criminal conflict that L. Tolstoi portrayed in the novel "Kreutzer Sonata" looks like. This short novellette was written in 1887-1889, when the artist was already an elderly person. The work immediately provoked a controversial reaction from readers, critics, legislators, philosophers.

The author's religious and philosophical reflections on the causes of the social defects and criminal acts that accompany the unfolding of the plot are still causing reactions of misunderstanding or outrage. The story is built in the form of the confession of the criminal. It is believed that through the mouth of Pozdnyshev (the killer), L. Tolstoi speaks and expresses his own philosophical views on important issues of human life, including criminal act. Pozdnyshev realized that the society in which he lives exists among the errors regarding the cardinal issues of love, sex, and marriage. "I have become a beast, a ferocious and cunning beast," - in these words he conveys his own state when he felt the need to beat and destroy. It is noteworthy that when telling about the moment of committing the criminal act, Pozdnyshev most often describes himself through the metaphor of "the beast that awoke in him"24. That once again proves to us a complex mechanism of committing a criminal act, a limitation of our idea of crime, the roots of which, in one way or another, must be sought in the individual criminal behavior of a person.

Philosopher E.A. Pozdniakov writes with all frankness that each person is not only capable of criminal act theoretically, but also commits it in practice under any favorable and unfair case ${ }^{25}$. However, along with this, it should be remembered that the tendency to destruction is biological in a person, and the commission of criminal acts, as a rule, is caused by social phenomena. The proof to the logical end of biological theories ultimately leads to the recognition of inferior (criminal) not only individuals, groups,

23 Фромм Э. Бегство от свободы. Человек для самого себя. Москва : Клиника глубинной психологии проф. П.С. Гуревича, Изд. «Изида», 2004. С. 317, 326.

24 Бачинін В., Рябініна О. Філософія злочину в «Крейцеровій сонаті» Л. Толстого. Вісник Академії правових наук Украӥни. 1997. № 2. С. 131-133.

25 Поздняков Э.А. Философия преступления: для тех, кто не боится потерять иллюзии. Москва : Изд-во Новоспасск. монастыря, 2001. С. 181. 
but also nations ${ }^{26}$. It is necessary to overcome in modern criminology the simplified conception of crime, to abandon the understanding of criminal act as a simple set of crimes, to widen the boundaries (territorial, national, mental, historical, temporal and other) and directions of cognition of crime, to study its constituent parts (juvenile delinquency, recidivism, female, professional and other crime) and find its origins. This is the only way to achieve results in the practical activities to combat crime $^{27}$.

\section{Modern approaches to the definion of crime}

The crime phenomenon we are considering is a call that there is a certain conflict in society, problems in a certain sphere (areas) of public life. In addition, crime is a phenomenon that has a significant evolutionary development ${ }^{28}$. It is recalled that high temperature is a sign of illness, that is, the disease reports itself due to the high temperature, and it manifests itself through that temperature, and the crime reports about itself, deficiencies in the activity and protection of state institutions through individual criminal acts $^{29}$. Today, the scientific world poses a rather problematic question: is it possible to punish a person for a criminal act if we do not have a clear idea of the "root causes" of crime, its essence, the source of the person's criminal behavior. Indeed, the success of the fight against crime depends on this idea, in fact. Ignorance is the result of our misunderstanding of this phenomenon and disease. However, at the same time, this is also recognition of a misunderstanding of the essence of human behavior in general ${ }^{30}$.

A promising study is the study of the link between crime and victimization ${ }^{31}$, which is a kind of adaptation of the deviance process to the process of changing the social structure ${ }^{32}$. Very often, it is the tense relationship between the offender and the victim that most significantly

\footnotetext{
26 Карпец И.И. Преступное общество. Москва: Молодая гвардия, 1983. С. 80-82.

27 Сметаніна Н.В. Межі пізнання злочинності у сучасному суспільстві. Правове життя сучасної Украӥни : матер. Міжнар. наук. конф. проф.-викл. Складу, Одеса, 20-21 квіт. 2012 р. Т. 2. / відп. за вип. В.М. Дрьомін / Нац. ун-т «Одеська юрид. акад..». Одеса : Фенікс, 2012. C. 342.

28 Гогель С.К. Курс уголовной политики в связи с уголовной социологией. Москва : ИНФРА-М, 2012. С. 18-21.

29 Философский энциклопедический словарь. Москва : ИНФРА-М, 2011. С. 553.

30 Рагимов И.М. Преступность и наказание : монография. Москва : ОЛМА Медиа Групп, 2012. С. $270-271$.

31 Потерпілий від злочину (міждисциплінарне дослідження) : монографія / кол. авт. ;за заг. ред. Ю.В. Бауліна, В.І. Борисова. Харків : Кроссроуд, 2008. 364 с.

32 Туляков В.О. Віктимологія (соціальні та кримінологічні проблеми). Одеса : Юрид. л-ра, 2000. 336 c.
} 
influences a person's determination to commit a criminal act. According to O.Yu. Yurchenko, the "criminal-victim relationship" category can and should become a real tool for predicting criminal reality and minimizing it by identifying not only future criminals but also potential victims ${ }^{33}$. A question also arises about the boundaries of the criminal potential of the victim's personality in the mechanism of the development of criminal assault.

When investigating crime, it should be borne in mind that the phenomenon of this phenomenon is very closely linked to the criminalization mechanism. Crime can be considered as a product of this mechanism. It is an evaluation shell that is filled with real socially dangerous activities ${ }^{34}$. At the same time Ya.I. Hilinskyi notes that there are no natural boundaries separating criminal behavior from non-criminal behavior. These limits are set by the legislator, and therefore they are artificial, relative, and criminalization is the result of the subjective will of the legislator. Moreover, crime itself is a complex social phenomenon that has no "natural" boundaries (unlike, for example, drug addiction, drunkenness, suicide) and is determined using a variety of criteria: 1) social danger, real harm, and 2) predictability by criminal law. The scientist believes that in reality there is no object that would be "criminal act" in its inherent, immanent properties, and attribute criminal act to relational (relative), conventional (contractual) social constructs. Ya.I. Hilinskyi calls crime a cogitative construct, a social and linguistic construct ${ }^{35}$. We believe that such a position of the scientist is due to the provisions of deviant logical science (which attributes crime to the basic forms of deviance), does not always fairly extend the boundaries of crime and makes it quite difficult to build an information model of crime and the possibility of its measurement. Though, as we know, there is some relativity in the understanding of deviance itself. This is a concept related to the integration and under-integration of social systems and subsystems. It is impossible to form a judgment about deviance or its absence without specific reference to the system or subsystem in which it operates ${ }^{36}$. Judgments about crime as a system in modern criminology is a contradictory and unproven statement, which is discussed in subsection of this study. At the same time,

33 Юрченко О.Ю. Роль віктимної поведінки потерпілих при вчиненні тяжких насильницьких злочинів проти життя та здоров'я особи в Україні : автореф. дис. ... канд. юрид. наук: 12.00.08; Нац. юрид. акад. України ім. Ярослава Мудрого. Харків, 2004. С.12.

34 Иншаков С.М. Исследование преступности. Проблемы методики и методологии : монография. Москва : ЮНИТИ-ДАНА : Закон и право, 2012. С. 302-311.

35 Гилинский Я.И. Девиантология: социология преступности, наркотизма, проституции, самоубийств и других «отклонений. Санкт-Петербург : Юрид. центр Пресс, 2004. С. $192-195$.

36 Парсонс Т. О социальных системах. Москва : Академический Проект, 2002. С. 360-363. 
the scientist aptly notes the need to develop a definition of crime, that would reflect the social nature, the essence of crime, and most importantly, there should be an indication of its specificity. The definition of crime should be specific to crime $^{37}$.

Whereas, O.M. Bandurka emphasizes that crime is an aggregate of socially dangerous acts, such acts that harm the material interests of people, create grief in families, collect a bloody harvest of killings and physical harm, and suffer huge economic losses for the country. At the same time, the scientist explores the link between crime and "background phenomena" (drinking, alcoholism, drug addiction, prostitution). There is a clear correlation between crime and these phenomena. By today, new forms of addictions, which primarily include gambling, multimedia additions, and dependence on the Internet, have begun to spread. An interesting and paradoxical situation can be traced: the person in the XX and XXI centuries becomes freer in economic, political, spiritual aspects, but in this way our contemporaries fall into the web of various addictions that distort the inner world and often push people to criminal acts. Deviant behavior is undoubtedly related to the personality of the individual, to the internal mental processes, but at the same time it is also mass, typical, and therefore social forms of behavior. Quality of life, personal safety, risks to children and their future are all directly linked to the prevalence of deviant phenomena in society. Society cannot calmly circumvent these phenomena; a certain reaction has always accompanied deviant behavior ${ }^{38}$.

Crime as a quality of society to produce many dangerous acts for humans (criminal multiplicity); D.A. Shestakov analyzes this phenomenon. He forms a new criminological concept: crime is not crime; crime is not a violation of the criminal code. The author proves that the criminal act is an act manifested externally, while crime is an individual's internal inclination to commit a crime, which he or she has the ability to act criminally in certain situations. The multiplicity of criminal acts committed and crime are correlated as a phenomenon and an essence, and the causes of the criminal acts are as something connecting between the second and the first. The crime is hidden, it is impossible to recognize it by a simple

\footnotetext{
37 Гилинский Я.И. Девиантология: социология преступности, наркотизма, проституции, самоубийств и других «отклонений. Санкт-Петербург : Юрид. центр Пресс, 2004. C. 191-192.

38 Бандурка О.М. Девіантологія: від теорії до профілактики. Девіантологічні читання в Харківському національному університеті внутрішніх справ (2008-2012рр.): 100 кращих тез доповідей : збірник / уклад. і заг. ред. І.П. Рущенка; вступ. слово С.М. Гусарова, В.І. Московця. Харків : Золота миля ; ХНУВС, 2013. С. 26.
} 
contemplation of the crimes committed and especially registered in society. Crime, as the scientist rightly points out, expresses the main thing that characterizes the process of criminal act reproduction, its internal, profound pattern, which is a private (individual) case of a more general pattern of multivariate, conflicting behavior of people who are objectively at odds with each other. Thus, crime is the very pattern by which a considerable number of criminal acts are perpetrated and the criminal acts themselves are the outward manifestation of $i t^{39}$. Yet the scientist also notes that criminology should not be confined to the criminal law definition of the concept of criminal act, but should develop its own criminological understanding of it, although it agrees that it will be vague and possibly get confused in distinguishing the same concepts in criminal law and criminology ${ }^{40}$. D.A. Shestakov proposes to understand crime as a social subsystem that expresses the capacity of society to commit crimes and emphasizes that not only the criminal acts recorded in the law but also other acts dangerous to human beings are subject to criminological understanding ${ }^{41}$. We proceed from the fact that the limits of crime cognition are nominally established by the Criminal Code. It is a criminal and legal model of understanding the limits of crime and is the ideal boundary of crime itself.

The question of whether crime has its own limits and ends was investigated by A.I. Dolhova. The author provides an ambiguous answer to this question: on the one hand, the limits of criminal behavior are determined by the laws of the state, and on the other - the human history is characterized by periods of legal and criminological arbitrariness (timelessness). Concepts such as extrusive and intrusive crime should be used to understand the intrinsic qualities of modern crime. Extrusive crime is a criminal phenomenon that is well understood by society as crimeful. Such crime is condemned and supplanted by the system of social and legal relations, and first of all by the rules of criminal law, from public life. At the same time, being displaced (extruded) from social, economic and political relations established in society, this part of crime creates its own relations, acquires a certain structure, forms its organized formations, develops its traditions and even

39 Преступность среди социальных подсистем. Новая концепция и отрасли криминологии / под ред. Д.А. Шестакова. Санкт-Петербург : Издательство «Юридический центр Пресс», 2003. С. 6-17.

40 Преступность среди социальных подсистем. Новая концепция и отрасли криминологии / под ред. Д.А. Шестакова. Санкт-Петербург : Издательство «Юридический центр Пресс», 2003. С. 22-24.

41 Шестаков Д.А. Уголовно-правовые перспективы криминологии. Право и демократия. 2004. Вып. 15. С. 249. 
gives rise to its criminal subculture. Most studies dealing with recidivism, professional and organized crime analyze extrusive crime.

Let's define another qualitative aspect of the phenomenon of crime intrusive crime, which carries out and continues to exert a much greater negative impact on social-economic processes in modern society. The main distinguishing feature of intrusive crime is that it intrudes naturally penetrating, embedding and beginning to play a significant role in the system of social, legal, financial, economic and other relations, gradually changing the political, cultural and spiritual life of society. Hypotheses have been put forward and evidence has been given that intrusive crime was the cause of social-economic and political crises in the $1990 \mathrm{~s}^{42}$. Research and determination of destructive and "constructive" crime, mimicry crime, intrusive-destructive-mimicry crime (IDM-crime) are ongoing ${ }^{43}$.

Determining the limits of crime cognition, it should also be borne in mind that the assessment of crime consists of an analysis of the characteristics of criminal offenses, the subjects of such acts, victims, material damage and other harm, other consequences of violations of the criminal prohibition. Generalization of data on perpetrators of crimes, typing of these persons allows to more accurately predicting the dynamics of crime, the extent of its impact on other social phenomena and processes ${ }^{44}$.

We consider that in determining the crime and its cognition limits, we must first of all proceed from the provisions of Article 11 of the Criminal Code of Ukraine: "A crime is a socially dangerous act (act or omission) provided for by this Code committed by the subject of a crime (Part 1 of Article 11). An act or omission is not a crime, although it formally contains the signs of an act provided for by this Code, but because of its insignificance does not constitute a public danger, that is, did not cause or could cause significant harm to an individual or a legal person, society or state (part 2 Article 11)" 45 .

We share the attitudes that crime may and should be viewed from the standpoint of criminology and criminal $\operatorname{law}^{46}$. In the criminal

42 Овчинский А.С., Чеботарева С.О. Матрица преступности. Москва: Норма, 2011. C. $67,69-70$.

43 Овчинский А.С., Чеботарева С.О. Матрица преступности. Москва: Норма, 2011. C. $70-78$.

44 Личность организованного преступника: криминологическое исследование : монография / под ред. А.И. Долговой. Москва : Норма: ИНФРА-М, 2013. С. 11.

45 Кримінальний кодекс України. URL: https://zakon.rada.gov.ua/laws/show/2341-14 (дата звернення: 25.01.2020).

46 Полный курс уголовного права : в 5 т. / под ред. А.И. Коробеева. Т. І: Преступление и наказание. Санкт-Петербург : Юрид. центр Пресс, 2008. С. 50-56. 
law approach, the focus is on the legal analysis of the corpus delicti in the unity of its four elements: the object, the objective side, the subject and the subjective side. The criminal act is analyzed as a relatively isolated act of guilty of criminal misconduct by a person. In criminological analysis, criminal act is considered, first, in the context of the interaction of the external environment and characteristics of the individual; secondly, not as a one-time act, but as a certain process that unfolds in space and time. The limits of criminological analysis of criminal act are generally wider than the limits of criminal investigation. At the same time, changes in criminal law are always taken into account in the analysis of crime. And criminal law, by evaluating and dividing all acts into criminal and noncriminal ones, thus delineates the limits of crime as a social phenomenon ${ }^{47}$. Therefore, in criminology, when studying the limits of crime cognition, it is more appropriate to use a criminological analysis of the concept of criminal act that has developed in criminal law, rather than developing your own definition of a criminal act; it may contradict, significantly expand and give rise to a double-aspect understanding of the nature of crime.

Crime has criminal and legal features ${ }^{48}$. Criminal acts include those acts that violate criminal law. Outside the criminal law assessment, there are no criminal acts (elements of crime) or crime as a whole. The criminal sphere is both socially dangerous and unlawful. Outside, there remain immoral acts and offenses known to other branches of law. The exceptions are the so-called "background" phenomena of crime. However, their criminology should only be studied in connection with the commission of those acts provided for by criminal law.

With the change of criminal law towards the criminalization or decriminalization of certain acts, the limits of crime become wider or narrower. The inclusion of various forms of deviant (delinquent) behavior in the concept of crime gives rise to an anti-legalist understanding of crime, that is characterized by extreme uncertainty, quite vague and subjective, and leads to the substitution of crime by an amorphous set of different types of behavior that deviates from social standards ${ }^{49}$.

Not all acts that we consider (subjectively everyone) to be criminal should be included in the criminal law framework. What is to be considered a crime

\footnotetext{
47 Курганов С.И. О стереотипах в криминологии. Государство и право. 1998. № 1. С. 62.

48 Даньшин И.Н. Общетеоретические проблемы криминологии : монография. Харьков : Прапор, 2005. С. 53-54.

49 Даньшин И.Н. Общетеоретические проблемы криминологии : монография. Харьков : Прапор, 2005. С. 54.
} 
and what is not is the question of the state of society, the politics of the state, the attitude to its citizens ${ }^{50}$. Criminal law should be formed and formulated with extreme caution, putting under protection of the criminal law only those areas of public relations that really need to be protected ${ }^{51}$. In addition, there is a thesis that each society has its own "crime saturation threshold" and it is the level of crime in society that determines the possibility of criminalizing or decriminalizing of certain acts ${ }^{52}$. If the level of crime in society is below the "saturation threshold", then society has the opportunity to make criminal laws tougher. And when crime reaches such a threshold, then it becomes a political issue, and there is a conflict between the rule of law and the relaxation of tension by "decriminalizing" certain actions. Examples can be found in discussions on legalizing drug use, prostitution, and gambling. We believe that the issue of criminalization of certain acts should be considered when the crime rate is below the saturation threshold but tends to increase. It should be remembered that excessive criminalization of actions can create in the society a certain field of social tension and the potential for every citizen to feel part of the criminal world.

\section{CONCLUSIONS}

There are also suggestions in the scientific literature to consider the concept of "crime" in the broad (philosophical) and narrow (social) sense $^{53}$. However, the view of crime from the philosophical categories of good and evil may not only be subjective but also make it impossible to characterize crime criminologically, which does not include the analysis of universal values. Although some scientists are trying to build a systematic model of the society of criminals - the abstract and perfect model, and calculated that the proportion of criminals in the world does not exceed $5,6 \%$ of the world's population, the proportion of juveniles and repeat offenders $-45 \%$ of all criminals, and $94,4 \%$ of people do not commit crimes. One of the criteria for such a system is the number of disharmony (i.e., alleged criminals) ${ }^{54}$. There is a doubt about the possibility of using such a system, because it does not take into account all indicators of crime, is based on statistics that do not have a single basis and is quite abstract.

\footnotetext{
50 Карпец И.И. Что такое криминология. Москва : Знание, 1986. С. 5.

51 Карпец И.И. Преступность как реальность.Вопросы философии. 1989. № 5. С. 87-97.

52 Фокс В. Введение в криминологию.Москва : Прогресс, 1985. С. 20; Ферри Э. Уголовная социология. Москва : ИНФРА-М, 2009. С. 240

53 Ли Д.А. Преступность в структуре общества. Москва : Русский мир, 2000. С. 41-46.

54 Ли Д.А. Преступность в структуре общества. Москва: Русский мир, 2000. С. 44, 81-83.
} 
The existence of the phenomenon of latent crime as a combination of actually committed, but not detected or such that as a result of certain other circumstances, did not become known to law enforcement and judicial authorities, crimes, the details of which are therefore not reflected in the official Criminal Law statistical reporting, significantly narrows the limits of crime cognition ${ }^{55}$. The classification of latent crime is based on various grounds: a) by the level of latency of individual criminal acts; b) by the mechanism of their formation. According to the first criterion, there are three groups. The first - criminal acts, the latency level of which does not exceed half the number registered. Such criminal assault has a minimum latency rate. The second group includes criminal acts, among which the number of latent ones is more than $50 \%$, but less than the total number of registered ones. This is a group of attacks with an average level of latency. And finally, the third group should include criminal acts which latency level exceeds the number of reported acts of a particular type. Thus, the new Criminal Procedure Code of Ukraine contains a number of articles that directly or indirectly contribute to the latentization of certain groups of crimes (Articles 477-479 of the CPC) ${ }^{56}$. Depending on the mechanism of formation of latent crimes, all their mass can be divided into four species classes, groups. The first group is a set of actual crimes that are not known to any law enforcement, officials or citizens. The second group - crimes known to both individuals and officials, but neither are reported to the appropriate authorities. The reasons for that may be different. The third group - criminal acts, the fact of which became known to the victim or an outsider, but they do not report about the crime to the criminal justice authorities due to the ambiguity of the situation or incorrect legal assessment. The fourth group is made up of crimes, which the body conducting the fight against crime has become aware of, but its representative for various reasons does not register the detected crime. As noted in the scientific literature, these classifications have a practical meaning ${ }^{57}$.

In the recent period, the study of latent crime phenomena is at a new level: the objects of study have expanded, latent crime and its types are studied more detailed and in complex, the latent crime of certain types of crimes has become the subject of study; the establishment of parameters

\footnotetext{
55 Оболенцев В.Ф. Латентна злочинність: проблеми теорії та практики попередження. Харків : Видавець СПД ФО Вапнярчук Н.М., 2005. С. 12.

56 Кримінальний процесуальний кодекс України. URL: https://zakon.rada.gov.ua/laws/ show/4651-17 (дата звернення: 27.01.2020).

57 Оболенцев В.Ф. Латентна злочинність: проблеми теорії та практики попередження. Вид. 2-ге, переробл. та доповн. Харків : Вид. ФОП Віленський Л.М., 2012. С. 47.
} 
of the shadow economy became especially relevant. There were also developed methods of studying the existing reality - mathematical, economic, as well as advanced methods that were used earlier. However, there is still no single concept in defining the very nature of latent crime is the hidden part of crime an independent phenomenon, or should we talk about latency as a property inherent in crime? In addition, a lack of awareness of the real state of crime gives rise to a number of negative circumstances; in particular, the society does not form a clear idea of the true prevalence of crime, the number of persons involved in crime, and the real "price" of crime. Latent, unpunished crime is a powerful lever of self-determination of crime that generates the continuation of the criminal path and attracts new persons to the orbit of unlawful conduct ${ }^{58}$. The phenomenon of latent crime complicates the possibility of influencing crime and combating this phenomenon, because the effectiveness of mechanisms of criminological forecasting and planning is reduced. Crime, however, should not be regarded as an evil for which there are no limits. There are limits of the impact on crime. Formation of the organizational and legal framework that would support reforms and ensure that criminal justice agencies continue to work more effectively is a strategically important task that must be solved on the following grounds: the political will of the top leadership of the state regarding the need to transform the criminal justice system into a powerful state mechanism for ensuring domestic security; phasing in and sequence of reforms, scientific approach to defining ways of implementation of reforms; taking into account the global experience of combating crime; ensuring the procedures and mechanisms for drafting legislative and other regulations necessary for the implementation of reforms ${ }^{59}$. Crime, having overcome certain stages in its development, starting from the idea of it as a manifestation of evil will, going from theories of extreme biologization to theories of extreme socialization, today should be considered as criminal practice of people, the limits of which are defined in the framework of the registered crime, and that much of it called latent crime, and the study of which is an independent criminological problem. The inclusion of various forms of deviant behavior into the limits of the crime cognition of deviant behavior will unjustly widen its boundaries, fill with manifestations of subjectivism and cast doubt on the possibilities of its quantitative and qualitative interpretation, which, of course, will not facilitate

\footnotetext{
58 Смирнов А.М. Латентная преступность в России : учебное пособие. Москва : Юрлитинформ, 2013. С. 10-12, 21-22.

59 Шакун В. Межі впливу на злочинність. Право Украӥни. 2009. № 7. С. 17-23.
} 
the criminological study of the phenomenon of crime ${ }^{60}$. The limits of crime cognition are now at such criminological and historical stages, based on the pluralism of scientific views of representatives of anthropological, classical, sociological, sociobiological concepts of crime. A study of the biological prepossession of people to deviant behavior, as well as recognition of the social nature of crime, proves that these views should not be overemphasizing. Crime, namely its various manifestations, has a different ratio of biological and social. Therefore, the depth of cognition of it should be on the verge of the social-biological nature of crime.

\section{SUMMARY}

The article deals with studying of crime cognition limits in modern Ukrainian criminology science. For the last decade sphere of public relations has increased significantly. It demands to make new researches, instill new terminology and units of measuring. The author understands crime as people's criminal practice, which is displayed like phenomenon consisting of multitude of crimes and persons who committed them. Such criminal practice must be interpreted both as for its quality and its quantity. It also should be analysed, as its displaying tells about the most problematic spheres of public life. Studying of crime displayings is made with help of criminology classification, as classification exercises systematic division and regulation of notions and things. Classification of crime displayings is called upon to build informational model of crime and gives possibility of its qualitative and quantative measuring. The evolutionary development of crime, its capacity for self-determination, self-reproduction, and the change of social relations, compels the legislator to introduce new offenses that were not previously known by criminal law, to timely and effectively counter crime displayings and protect social institutions.

\section{REFERENCES}

1. Карпец И.И. Преступность как реальность. Вопросы философии. 1989. № 5. С. $87-97$.

2. Рагимов И.М. Преступность и наказание : монография. Москва : ОЛМА Медиа Групп, 2012. 304 с.

3. Парсонс Т. Система современных обществ. Москва : Аспект Пресс, 1998. $270 \mathrm{c}$.

4. Бабаев М.М., Квашис В.Е. Преступность и политика в общественных формациях переходного периода. Право и политика. 2001. № 2. С. 124-125.

60 Сметанина Н.В. Границы познания преступности в современной постсоветской криминологии. Журнал науч. публикаций аспирантов и докторантов. 2013. № 5. С. 329. 
5. Statistics on Crime in Ukraine. URL: https://www.gp.gov.ua/en/ statinfo.html (accessed 08.09.2019).

6. Шабалин В.А. Политика и преступность. Государство и право. 1994. № 4. С. 43-52.

7. Травис Дж. Международные стратегии предупреждения преступности в обществах переходного периода: проблемы и перспективы. Право и политика. 2001. № 2. С. 126-130.

8. Васильченко Г.С. Страх перед преступностью в современном обществе. Правова держава. 2001. № 3. С. 116-119.

9. Ройбанд К.Х. От истерии вокруг преступности к нормальному состоянию? Сочиологические исследования. 2001. № 11. С. 77-83.

10. Аванесов Г.А. Преступность и социальные сословия. Криминологические рассуждения: монография. Москва: ЮНИТИДАНА, 2010. 79 с.

11. Кристи Н. Контроль над преступностью как индустрия. Вперед, к ГУЛАГу западного образца. Санкт-Петербург : Алетейя, 2012. 208 с.

12. Личность организованного преступника: криминологическое исследование : монография / под ред. А. И. Долговой. Москва : Норма: ИНФРА-М, 2013. 368 с.

13. Долгова А.И. Криминология : учебник. Москва : НОРМА, $2002.272 \mathrm{c}$.

14. Криминология : учебник для вузов/ под общ. ред. А.И. Долговой. Москва : НОРМА,, 2000. $784 \mathrm{c.}$

15. Бачинин В.А. Философия права: конспект лекций. Харьков : Консум, 2002. 368 с.

16. Фокс В. Введение в криминологию.Москва : Прогресс, 1985. 312 с.

17. Фромм Э. Анатомия человеческой деструктивности. Москва : ООО «Издательство АСТ-ЛТД», 1998. 672 с.

18. Фромм Э. Бегство от свободы. Человек для самого себя. Москва : Клиника глубинной психологии проф. П.С. Гуревича, Изд. «Изида», 2004. 399 c.

19. Бачинін В., Рябініна О. Філософія злочину в «Крейцеровій сонаті» Л. Толстого. Вісник Академії правових наук України. 1997. № 2. С. 131-140.

20. Поздняков Э.А. Философия преступления: для тех, кто не боится потерять иллюзии. Москва : Изд-во Новоспасск. монастыря, 2001. 576 с.

21. Карпец И.И. Преступное общество. Москва : Молодая гвардия, 1983. $174 \mathrm{c}$.

22. Сметаніна Н.В. Межі пізнання злочинності у сучасному суспільстві. Правове життя сучасної України : матеріали Міжнар. наук. конф. проф.викл. складу, Одеса, 20 - 21 квіт. 2012 р. Т. 2 / відп. за вип. В.М. Дрьомін / Нац. ун-т «Одеська юрид. акад.». Одеса : Фенікс, 2012. С. 342-343. 
23. Гогель С.К. Курс уголовной политики в связи с уголовной социологией. Москва : ИНФРА-М, 2012. 386 с.

24. Философский энциклопедический словарь. Москва : ИНФРА-М, $2011.570 \mathrm{c}$.

25. Потерпілий від злочину (міждисциплінарне дослідження) : монографія / кол. авт.; за заг. ред. Ю.В. Бауліна, В.І. Борисова. Харків : Кроссроуд, 2008. 364 с.

26. Туляков В.О. Віктимологія (соціальні та кримінологічні проблеми). Одеса : Юрид. л-ра, 2000. 336 с.

27. Юрченко О.Ю. Роль віктимної поведінки потерпілих при вчиненні тяжких насильницьких злочинів проти життя та здоров'я особи в Україні : автореф. дис. ... канд. юрид. наук : 12.00.08; Нац. юрид. акад. України ім. Ярослава Мудрого. Харків, 2004. 16 с.

28. Иншаков С.М. Исследование преступности. Проблемы методики и методологии : монография. Москва : ЮНИТИ-ДАНА: Закон и право, 2012. $335 \mathrm{c}$.

29. Гилинский Я.И. Девиантология: социология преступности, наркотизма, проституции, самоубийств и других «отклонений. СанктПетербург : Юрид. центр Пресс, 2004. 520 с.

30. Парсонс Т. О социальных системах. Москва: Академический Проект, 2002. 832 с.

31.Бандурка О.М. Девіантологія: від теорії до профілактики. Девіантологічні читання в Харківському начіональному університеті внутрішніх справ (2008-2012 рр.): 100 кращих тез доповідей : збірник / уклад. і заг. ред. І.П. Рущенка ; вступ. слово С.М. Гусарова, В.І. Московця. Харків : Золота миля ; ХНУВС, 2013. С. 26-29.

32. Преступность среди социальных подсистем. Новая концепция и отрасли криминологии / под ред. Д.А. Шестакова. Санкт-Петербург : Издательство «Юридический центр Пресс», 2003. 353 с.

33. Шестаков Д.А. Уголовно-правовые перспективы криминологии. Право и демократия. 2004. Вып. 15. С. 240-250.

34. Овчинский А.С., Чеботарева С.О. Матрица преступности. Москва : Норма, 2011. 112 с.

35. Кримінальний кодекс України. URL: https://zakon.rada.gov.ua/laws/ show/2341-14 (дата звернення: 25.01.2020).

36. Полный курс уголовного права : в 5 т. / под ред. А.И. Коробеева. T. I: Преступление и наказание. Санкт-Петербург : Юрид. центр Пресс, 2008. 1133 c.

37. Курганов С.И. О стереотипах в криминологии. Государство и право. 1998. № 1. С. 61-65. 
38. Даньшин И.Н. Общетеоретические проблемы криминологии : монография. Харьков : Прапор, 2005. 224 с.

39. Карпец И.И. Что такое криминология. Москва : Знание, 1986. 64 с.

40. Ферри Э. Уголовная социология. Москва : ИНФРА-М, 2009. 658 с.

41. Ли Д.А. Преступность в структуре общества. Москва : Русский мир, 2000. 153 с.

42. Оболенцев В.Ф. Латентна злочинність: проблеми теорії та практики попередження. Харків : Видавець СПД ФО Вапнярчук Н.М., 2005. 128 с.

43. Кримінальний процесуальний кодекс України. URL: https://zakon.rada.gov.ua/laws/show/4651-17 (дата звернення: 27.01.2020).

44. Оболенцев В.Ф. Латентна злочинність: проблеми теорії та практики попередження. Вид. 2-ге, переробл. та доповн. Харків : Вид. ФОП Віленський Л.М., 2012. 119 с.

45. Смирнов А.М. Латентная преступность в России : учебное пособие. Москва : Юрлитинформ, 2013. 184 с.

46. Шакун В. Межі впливу на злочинність. Право Украӥни. 2009. № 7. C. $17-23$.

47. Сметанина Н.В. Границы познания преступности в современной постсоветской криминологии. Журнал науч. публикаций аспирантов и докторантов. 2013. № 5. С. 327-330.

\section{Information about author: Smetanina N. V., Ph.D.,} Assistant Professor of the Department of Criminology and Penitentiary Law Yaroslav Mudryi National Law University 77, Pushkinskaya str., Kharkiv, Ukraine

DOI https://doi.org/10.30525/978-9934-588-43-3/2.18 